IZA DP No. 5593

The Intergenerational Transmission of Employers in Canada and Denmark

Paul Bingley

Miles Corak

Niels Westergård-Nielsen

March 2011 


\title{
The Intergenerational Transmission of Employers in Canada and Denmark
}

\author{
Paul Bingley \\ National Institute of Social Research, Copenhagen \\ Miles Corak \\ University of Ottawa \\ and IZA \\ Niels Westergård-Nielsen \\ Aarhus School of Business, Aarhus University \\ and IZA
}

Discussion Paper No. 5593

March 2011

IZA

P.O. Box 7240

53072 Bonn

Germany

Phone: +49-228-3894-0

Fax: +49-228-3894-180

E-mail: iza@iza.org

\begin{abstract}
Any opinions expressed here are those of the author(s) and not those of IZA. Research published in this series may include views on policy, but the institute itself takes no institutional policy positions.

The Institute for the Study of Labor (IZA) in Bonn is a local and virtual international research center and a place of communication between science, politics and business. IZA is an independent nonprofit organization supported by Deutsche Post Foundation. The center is associated with the University of Bonn and offers a stimulating research environment through its international network, workshops and conferences, data service, project support, research visits and doctoral program. IZA engages in (i) original and internationally competitive research in all fields of labor economics, (ii) development of policy concepts, and (iii) dissemination of research results and concepts to the interested public.
\end{abstract}

IZA Discussion Papers often represent preliminary work and are circulated to encourage discussion. Citation of such a paper should account for its provisional character. A revised version may be available directly from the author. 


\section{ABSTRACT \\ The Intergenerational Transmission of Employers in Canada and Denmark*}

The intergenerational transmission of employers between fathers and sons is a common feature of labour markets in Canada and Denmark, with 30 to $40 \%$ of young adults having at some point been employed with a firm that also employed their fathers. This is strongly associated with the first jobs obtained during the teen years, but for four to about six percent it also refers to the main job in adulthood. In both countries the transmission of employers is positively associated with paternal earnings, rising distinctly and sharply at the very top of the father's earnings distribution, and has implications for the intergenerational transmission of earnings. Mobility out of the bottom has little to do with inheriting an employer from the father, while the preservation of high income status is distinctly related to this tendency. These findings stress that child adult outcomes are related to the structure of labour markets, and underscore the role of resources parents have - though information, networks, or direct control of the hiring process - in facilitating the job search of their children.

JEL Classification: J62, J64, J24

Keywords: intergenerational mobility, job search, equality of opportunity

Corresponding author:

Miles Corak

Graduate School of Public and International Affairs

University of Ottawa

Desmarais Building, Room 11156

55 Laurier Avenue East

Ottawa, Ontario K1N 6N5

Canada

E-mail: corak@iza.org

\footnotetext{
* We acknowledge with appreciation comments on earlier drafts of this paper by Paul Gregg, Markus Jantti, Tim Smeeding, and James Wilson. The financial support of the Russell Sage Foundation is acknowledged with thanks, and the authors also gratefully acknowledge the exemplary research assistance of Mikkel Sølvsten as well as the advice of Patrizio Piraino. Corak is grateful for the financial support of the Social Sciences and Humanities Research Council of Canada through a Standard Research Grant.
} 


\section{The Intergenerational Transmission of Employers in Canada and Denmark}

\section{Introduction and motivation}

Children must advance through a whole series of transitions at different points in their lives, which to varying degrees may all have a bearing on their ultimate labour market success as adults. This paper addresses the relationship between parental income and the labour market outcomes of teenagers and young adults. This gradient refers to the relationship between family circumstances during adolescence and early adult outcomes. This is an important transition in a child's life because it relates directly to some of the issues addressed by Roemer (2004) in his concern over the relationship between measures of generational mobility, equality of opportunity, and the appropriate role for public policy.

To perhaps overly simplify his argument, a strong gradient in incomes across the generations could reflect genetic and other hereditary endowments associated with the early years. The transmission of family values, preferences, and other inherent characteristics like motivation, may permit parents who are relatively well advantaged to raise children who in turn go on to be relatively advantaged adults. If these characteristics are valued by labour markets over time, there will also be a correlation in the earnings of the two generations. Different societies will draw the line between family and the state in different ways, so the correlation in incomes across the generations would not necessarily be viewed as indicating inequality of opportunities. In other words, if hereditary endowments associated with the very nature of families and how they raise their children are driving the correlation in adult outcomes, then the case for public policy intervention - assuming it is effective - would involve a cost in terms of liberty and autonomy that may or may not be acceptable. 
At the other extreme a strong correlation in parent-child incomes could also reflect other investments later in life, particularly the role of networks or direct control in the hiring process that influence the opportunities for employment in the labour market. The children of relatively well-advantage parents could benefit by getting jobs - either temporary jobs that facilitate the transition from schooling to work, or career jobs that determine their permanent income- - by relying upon the contacts and information their parents may share with them, or for that matter through the direct or indirect control parents may have in the hiring process of their employers. This perspective puts the emphasis on how social and labour market institutions function and interact with family background to determine adult outcomes. For example, Roemer points out that if nepotism is the source of the cross-generational income-income gradient many citizens of the OECD countries may not see this as reflecting equal opportunities, and there may be a stronger consensus on the role for government intervention.

The objective of this paper is to inform a discussion of this sort. More specifically we document the extent of the intergenerational transmission of employers, and in a descriptive way relate it to the transmission of earnings in two relatively mobile countries: Canada and Denmark. To be precise, we study the degree to which sons - both during their teen years as they are making the transition from full-time schooling to full-time employment, and during their young adult years once they have established themselves in what will arguably be their career jobswork for the same employer as their fathers. Our choice of these two countries is certainly driven by the availability of data with sufficient and appropriate detail, but is also important in a substantive sense because it is generally accepted that they are among the most mobile countries when comparisons are made of earnings inter-generationally. The elasticity of father-son earnings is about 0.2 or even less in both countries, compared to 0.4 to 0.6 in countries such as the United States, the United Kingdom, and France (Corak 2006). Yet at the same time, they are very different in the structure of their labour markets: Denmark being a geographically much smaller and less diverse country. However, it has high equality of earnings and incomes and a high degree 
of intergenerational mobility. This said, despite high unionization rates, the degree of employee turnover and general flexibility suggests that the Danish labour market has more in common with North America than with continental Europe. Furthermore, Denmark belongs to the group of countries with the lowest returns to schooling (Harmon et al 2001). Canada is less equal in crosssectional outcomes, less unionized, and has a higher return to human capital. As such we feel that this comparison may have broader relevance, and suggest avenues for future research among a wider set of countries. If the intergenerational transmission of employers is significant in these countries, and if it is strongly related to generational earnings mobility, then even relatively low correlations in intergenerational earnings may be cause for concern, and by implication raises the need for closer examination of the underlying reasons for higher correlations in other countries.

Our major finding is that the intergenerational transmission of employers is both very significant and very similar across these two countries. It is a common aspect of how families and labour markets interact, with about 30 to $40 \%$ of the young men we study having at some point been employed with a firm that also employed their fathers. This reflects the first jobs these individuals obtain during their teen years. As such our analysis notes that parents continue to invest and influence outcomes for their children well into the teenage and young adult years. In addition we find that about four to about six percent of the cohorts we study have their main job in adulthood at an employer who provided their fathers with a main job some 15 years earlier. Second, we also find that these patterns are positively associated with paternal earnings and to remarkably similar degree across the two countries, rising distinctly and sharply at the very top of the earnings distribution. Finally, we document the fact that these patterns have implications for the intergenerational transmission of earnings. Upward mobility of teenagers raised in low income has little to do with inheriting an employer from the father, but the preservation of high income status is strongly related to this tendency. The results from a series of quantile regressions suggest that the inheritance of employers cuts against this the notion of equality of opportunity in the sense that Roemer has used that term. 
2. Some definitions and the nature of the data

Our analysis focuses on parental investments at the latter point in the child's teen years, in particular the teen years associated with secondary schooling (15 to 18 years of age) and the early adult years associated with the transition to the labor market or to higher education (19 to 22 years of age). For our purposes adult outcomes are measured at about the age of 30 or a little later.

These definitions reflect in part the characteristics of our administrative data, but also the particular type of parental investment upon which we focus. During the teen years children are beginning to interact with the labor market, finding their first jobs and developing a work ethic, yet many are still completing their education. During their early 20s some have made a permanent transition to the labour market, others are continuing their education, but in most cases occupational choices are beginning to crystallize.

There is a sense that our data may be unique, but our hope is that their development will spur similar research in other countries. They permit us to examine the extent to which children are employed at the same firm as their fathers, and the consequences this has for long run labour market outcomes in adulthood. An observation of employment in the same firm as the father is taken as an indicator that parents have a network upon which children can rely in their job search, that they are employed with firms that have hiring rules favoring the children of employees, or that they themselves have some control over the hiring process. These are all resources that can be of benefit to the child in making the transition to the labor market, and that may also have long run implications by translating any given level of education into employment with a particular firm.

Our analysis relies on information that in principle represents the entire population of particular cohorts of young men in both countries. For Canada we base the analysis on about 70,000 individuals who come close to representing the population of a cohort of men born in 1963. These individuals are followed to the age of 33 . These administrative data-which are 
based on income tax returns - are linked to their fathers and mothers. Just as importantly the data also contain identifiers on up to four firms per year for the fathers and sons from the time the child was 15 years of age to 33. Corak and Piraino $(2011,2010)$ use the same data, and some of the Canadian information reported here is drawn from Corak and Piraino (2011).

These data are based upon on individual income tax returns that have been grouped into families. Our sample is drawn from 1.9 million men who are linked to their fathers- not necessarily their biological fathers — if they filed an income tax return between 1982 and 1986 while still living at home. From this data we select the cohort born in 1963, the oldest cohort of sons available to us. To remain in the analytical sample the father must have positive earnings in each of the five years the son was 15 to 19 years old. Sons must have positive earnings in each of three years, 1994 to 1996 . If either the father or the son reports no earnings over these time horizons the pair is not included in the analysis. This would imply, for example, those who are self-employed, and never report any earnings over the five and three year horizons, are not part of the analysis. As mentioned the sample size is about 71,000 observations, representing 84,000 individuals when appropriately weighted. ${ }^{1}$ Fathers are on average 47 years old when their earnings are calculated.

For Denmark the data are more extensive. They come from the administrative sources in existence since 1980, and contain information on all individuals and employers and the length of time they are matched. We construct the data to permit a focus on the same age cohort as the Canadian, but information on younger and older cohorts up to their early 40s is also available. The sample size is just under 195,000 .

The Danish register data cover the entire population of about five million people, but our analysis takes 515,986 sons from the 1965 to 1976 birth cohorts as its starting point. The link

\footnotetext{
${ }^{1}$ These restrictions are imposed in order to minimize the role of measurement error in earnings, as stressed in the literature on intergenerational earnings mobility (Solon 1992, 1989). We also require that the earnings of both sons and fathers must be above the bottom percentile thereby avoiding some suspected measurement errors in the data.
} 
between fathers and sons requires that they live at the same address together at one point of time after 1965 . On this basis we identify 402,027 father-son pairs. Of these 274,296 have an identifiable main employer, and there are 198,718 cases with the father reporting positive earnings in each of the five years when the son was 15 to 19 years old. We use the earnings of sons when they are 30 years old. Danes finish higher education relatively late, so for many 30 years of age is the beginning of their full-time careers.

In both countries the analysis refers to employment in the private sector only. The only exception to this is the inclusion of municipal governments in the Canadian case. Otherwise the observation that both father and son work for the government - in Canada either the federal or one of the provincial governments - is not coded as a match. This is because the employer identifier for the government captures all possible jobs in all possible regions, many of which will have nothing to do with direct parental influence. This said the findings should be interpreted as an understatement of the true extent to which employers are transmitted cross-generationally. Between 6 and $8 \%$ of sons work in the public sector at ages 18 and older. In Denmark, the nature of municipal, region and State identification would include way too many "false" matches due to the extensive public sector paired with large administrative units. Finally, in both countries an employer should be understood to mean an "enterprise", rather than a particular plant.

Our analysis is based upon two complementary definitions of same firm employment across the generations. The first is a broad definition meant to reflect the network of employers of which the father has direct knowledge by virtue of having worked with them. We define a binary indicator of same firm employment that takes a value of 1 when the son at any particular age from 16 to 30 in Denmark, and up to 33 in Canada, was in that year, or in any previous year, employed with any employer that also employed his father in any previous year back to the year the son was 15 years old. This is a time-varying indicator, and we use its value when the son is in his early 30 s as the basis for our analysis. We refer to this value as "ever same firm." 
Figure 1 offers the pattern in this indicator for sons in both countries from the age of 16. On the basis of this indicator the proportion of same firm employment can only increase with time. At the age of $1611 \%$ of the Danish sons in our sample are working with an employer who had employed their fathers in the previous year; $8 \%$ of Canadian sons are in a similar situation. These proportions rise sharply in both countries during the teen years, reaching respectively $22 \%$ and $29 \%$ at age 20 . The intergenerational transmission of employers is, in other words, an important aspect of finding the first jobs teenagers hold. After the age of about 23 to 24 the proportion of sons who have ever been employed with a previous employer of their fathers begins to level and does not increase very much at all after about the age of 26. By their late twenties or early thirties $28 \%$ of Danes and $40 \%$ of Canadians have at some point worked with an employer for which their fathers had also worked. ${ }^{3}$

The second indicator we derive is intended to reflect the permanent earnings of the son, and is based upon the main employer at age 30 or so. This is the employer accounting for the majority of the son's earnings over a three year period. This in turn is related to the employer accounting for the majority of the father's earnings over the five year period when the son was 15 to 19 years old. We refer to this as "same main employer," and our intention is to relate this measure to the degree of intergenerational transmission of earnings. It is for this reason that we define the indicator over a period of successive years, reflecting the averaging in earnings we also undertake to reduce the role of transitory fluctuations and come closer to a measure of permanent income. In Denmark we find that $4.0 \%$ of sons work for the same main employer as their fathers, while in Canada $5.6 \%$ of sons are in the same situation.

\footnotetext{
${ }^{3}$ It should be noted that part of the pattern of change in the early years of the part of the life-course we examine could be due to a mechanical effect reflecting the fact that we only begin to examine the father's employers when the son was fifteen years of age. As the son ages the incidence of same firm employment will rise because more years of information becomes available on the father's employment history. This said, this effect would appear to have worked itself out by the end of the period we examine, which is our main analytical concern.
} 
The slightly higher incidence of same firm employment in Denmark at the youngest ages could reflect the structure of apprenticeship programs, which facilitate the school to work transition in a more formal way than in Canada. On the other hand, the higher overall proportions of same firm and same main firm employment in Canada may reflect the much larger geographic dispersion of employment combined with less mobility between regions. For example, if the labor market is segmented with high costs of mobility between potential employers, then it is more likely that simply by random chance sons will be employed with the same firms because of the limited job opportunities available in their region of residence. Corak and Piraino (2011) examine various aspects of this possibility and note through a series of counterfactual simulations that at the very most this accounts for one to 1.5 percentage points of the $5.6 \%$ incidence of same firm employment. This result is based upon a simulation in which the son's job mobility is restricted to the same industry and same finely defined region as the father. This leaves a significant fraction of the overall incidence open to family influences, but combined with a lower average firm size in Denmark may be large enough to explain some of the cross-country difference in the overall incidence.

3. The intergenerational transmission of employers and paternal earnings

The major objective of our analytical work is to document the gradient between parental earnings and the degree to which sons inherit their father's employer. Figures 2 and 3 present the incidence of same firm employment, for each of our two indicators, according to the percentile of the father's earnings distribution. The patterns are clearly similar across the two countries.

Figure 2 shows that the incidence of sons ever having worked for an employer that also employed the father follows a U-shaped pattern. Generally the incidence is lowest in the middle part of the father's earnings distribution, and higher in the bottom and top $20 \%$. The other notable pattern is the sharp spike in the incidence at the very top of the earnings distribution in both countries. In Denmark the incidence of same firm employment rises distinctly above the $90^{\text {th }}$ 
percentile, where it is always above $30 \%$. But above the $95^{\text {th }}$ percentile it is well above this proportion increasing to $35 \%$ and just surpassing $50 \%$ at the top percentile. In Canada the pattern is similar, with about $45 \%$ of sons having had the same employer as their father when the father is in the $90^{\text {th }}$ to $95^{\text {th }}$ percentile of his earnings distribution, and rising to above $50 \%$ for higher earning fathers before almost reaching $70 \%$ in the case of top percentile fathers.

Figure 3 offers similar information for the incidence of the transmission of same main employers. In Denmark the pattern is roughly constant throughout the paternal earnings distribution, increasing perhaps from generally below $4 \%$ to about that level. In Canada there is a clear linear increase, rising steadily from about four to five percent in the lower fifth of the father's earnings distribution, to six to eight percent in the upper third or so. But again in both countries there is a noticeable increase in the chances at the very top, with fully 10 to $15 \%$ of the sons of top percentile fathers employed as young adults at the same main employer that employed their fathers some 10 to 15 years earlier.

These bivariate relationships between paternal earnings and the chances sons will have the same employer as the fathers are robust to a host of controls. We estimate a series of linear probability models of the incidence of same firm employment for both definitions that include a number of control variables that are common to the two countries. They include characteristics of the father such as age, indicators for the source of income, and number of employers, and characteristics of the firm, industry, and controls for the diversity of employment opportunities in the local labor market: whether the firm was still in existence during the son's adulthood, firm size, the industry employment growth rate, two-digit SIC industry indicators, and relatively fine indicators of location, including measures of whether the son resided in an urban area or not.

Our main interest is in the results for two variables: the natural logarithm of the father's earnings (and its square), and an indicator for the presence of self-employment income. The former documents the gradient between income and the transmission of employers net of some basic controls associated mostly with industrial structure that may determine the chances sons 
will be employed with their father's firm. For example, as suggested, if the local labor market is not very diverse and if there is little inter-regional mobility it is likely that sons will be employed with the same employer as their fathers by virtue of the fact that job opportunities are not available with many other firms. Similarly, sons are more or less likely to be employed in the same firm as their fathers if that firm is experiencing significant increases or decreases in employment by virtue of being in a growing or declining industry, or if firms tend to large in size relative to the labor force. It is also sometimes noted that unionized firms may have implicit or explicit hiring rules that favor the children of employees (Shea 2000).

This said, we also highlight the role of self-employment income as its presence may indicate that the father could have direct control over the hiring process by virtue of firm ownership. We should note that the variable used is an indicator of the presence or not of selfemployment income among the fathers total income, and need not strictly have its origin in the same firm from which he obtained his earnings. We can only identify the employer that was the source of the earnings, and it is this employer that is used in deriving the incidence of the generational transmission of employers. To the extent that self-employed fathers also pay themselves earnings, the employer will be the same.

Table 1 presents a summary of the complete least squares regression results focused these selected variables. In both countries there is a clear quadratic relationship between paternal earnings and same firm employment for both definitions. The values of the coefficients suggest that the relationship is parabolic, always increasing and increasing at a greater rate with higher and higher levels of father's earnings. As such the general patterns displayed in Figures 1 and 2 seem, for the most part, to hold up in a multi-variate context. Further, the relationship between the chances of being employed at the same employer as one's father are positively and strongly related to whether or not the father reported having some self-employment income. In the case of Denmark the presence of self-employment income implies that the probability of same-firm employment is higher by 33.2 and 3.7 percentage points for respectively ever same employer and 
same main employer. We ascribe these rather large estimates to the incentives associated with tax filing where self-employed can exploit the tax-free allowance for their sons by having them on the payroll. In Canada the similar figures are five percentage points for ever same employer, off of an overall average of about $40 \%$, and 0.5 percentage points for same-main-employer, compared to an average of just less than $6 \%$. As such, net of the influence of total paternal earnings, the presence of self-employment seems more strongly associated with the chances of ever getting a job with an employer the father had than with the chances of getting a career job with the same career employer as the father.

4. The intergenerational transmission of employers and adult earnings The finding that there is a clear positive relationship between paternal earnings and the chances of same firm employment raises the issue of how relevant the transmission of employers is to the intergenerational transmission of earnings. In order to document this relationship we focus on the transmission of main employers, as these are most closely related to the adult earnings that form the basis for intergenerational earnings studies. Using Canadian data Corak and Piraino (2011) report that the presence of same main employers across the generations does not appreciably change the overall average elasticity between father and son earnings in large measure because there are only about six percent of sons with same main employers as their fathers. But their findings, and the results we document above, suggest that this influence could well vary across the parental earnings distribution; the possibility of non-linearities in the intergenerational elasticity being assumed away in the linear specification common in this literature. Accordingly in the descriptive analysis that follows we pay particular attention to differences across the paternal and child distributions, and begin by focusing on certain parts of the transition matrices. But we also note that transition matrices and estimates of the average intergenerational earnings elasticity do not directly inform a discussion about equality of opportunity for the reasons 
highlighted by Roemer (2004), and we therefore then frame the analysis in a way a more appropriate way to address this issue.

Panel A of Figure 4 presents slices of the full quartile transition matrix between father and son earnings for both countries. ${ }^{4}$ The earnings quartiles of sons raised by bottom quartile fathers are presented in the left panel of the figure, while that for sons raised by top quartile fathers are offered in the right panel. These rows of the transition matrix are very similar between the two countries. In Canada about $35 \%$ of sons born to bottom quartile fathers become bottom quartile adults; in Denmark about $30 \%$ do so. The extent of upward mobility for these young men is even more similar: $37 \%$ of Canadians rise to the top half of the distribution as do $39 \%$ of Danes, with $16 \%$ in both countries managing the largest move to the top quartile. The similarities are also present at the upper end of the paternal earnings distribution. In both countries there is more stickiness at the top of the distribution than at the bottom, with almost $40 \%$ of sons raised by top quartile fathers also attaining the top quartile of the earnings distribution in the next generation. In both countries 37 to $38 \%$ of these sons fall to the bottom half of the earnings distribution, with $17 \%$ of Canadians falling fall to the bottom compared to $21 \%$ of Danes.

Panel B shows how these patterns are related to the intergenerational transmission of main employers, with again the left panel indicating the situation of sons born to bottom quartile fathers and the right indicating that of those originating in the top quartile. In both countries the incidence of same main employer is about 3 to 4 percent for the children of the relatively poor fathers regardless of whether they remain poor or whether they move to the very top of their earnings distribution (though at $2.3 \%$ a bit lower for Danes who manage to reach the top quartile). This is in sharp contrast with the experience of sons born to rich fathers. There is a clear gradient in the proportion having the same main employer as the father according to the relative earnings outcome of the son. Sons of top quartile fathers who fall to the bottom quartile are not very likely to have the same main employer as the father: only 2 to $3 \%$ do so, a proportion that is even less

\footnotetext{
${ }^{4}$ The complete quartile transition matrices are appended as Appendix Table 1.
} 
than bottom quartile sons. In sharp contrast, this incidence is much higher if these sons remain in the top half of the earnings distribution, and particularly if they remain in the same quartile as their fathers. In Canada almost 12 percent (or twice the overall average) of sons who are in the top quartile obtain their relatively high earnings from the same main employer that employed their father. Though there is also a clear gradient in the Danish context, the pattern is not as sharp as in Canada.

Table 2 offers evidence that is more directly related to equality of opportunity by presenting the results from quantile regressions of the standard linear model, but in a way that permits the intergenerational earnings elasticity to change according to whether or not the son held a job with the same main firm as his father. The following fully interacted model is estimated at the $10^{\text {th }}, 25^{\text {th }}, 50^{\text {th }}, 75^{\text {th }}$ and $90^{\text {th }}$ percentiles:

$$
\ln Y_{i, t}=\alpha+\beta \ln Y_{i, t-1}+\beta_{1} \ln Y_{i, t-1} \times \text { SameFirm }_{i}+\gamma_{1} \text { SameFirm }_{i}+\varepsilon_{i}
$$

where $\ln Y_{i}$ is a measure of the natural logarithm of permanent earnings for an individual in family $i, t$ indexes generations, and SameFirm is a binary indicator taking the value of 1 when the main firm is the same across generations. Our interest is with the coefficient, $\beta_{1}$, the interaction between paternal earnings and SameFirm, and how its value changes across the percentiles of the sons' earning distribution. If statistically significant the implication would be that the intergenerational earnings elasticity is $\left(\beta+\beta_{1}\right)$ for those with the same main firm as their fathers. The first two columns of the table also offer results from a model with no interaction effects.

Our interpretation of these results borrows from Grawe (2004), who suggests that the use of quantile regressions offers an appropriate way to empirically implement the concerns raised by Roemer (2004). Roemer states that "equality of opportunity ... views inequalities of outcome as indefensible, ethically speaking, when and only when they are due to differential circumstances. Inequalities due to differential effort are acceptable." (2004, page 50) Grawe echoes the view that a focus on average outcomes, as for example in the standard linear regression to the mean model, 
is not an appropriate indicator of equality of opportunity because abilities and preferences that have value in the market place will be correlated with the parents' economic circumstances. His interpretation of Roemer is to suggest "comparing children with similarly successful outcomes relative to other children born to similar families. That is, ... [compare] the highest-, median-, or lowest-earning child born to low-earning parents to the highest-, median-, or lowest-earning child born to high-earning parents." (Grawe, 2004 page 59) Quantile regression is one way of doing this. Equality of opportunity would be signaled by a low vale for $\beta$ among all sons who are successful in the labour market, those who for example have earnings at the $90^{\text {th }}$ percentile. If a significant gradient between parent and child earnings exists for these high achieving sons, then the suggestion is that in spite of having the abilities and preferences for labour market success the sons of low-income parents remain hampered by the economic circumstances of their family background, a situation that cannot be characterized as equality of opportunity.

The results for Canada show that the intergenerational earnings elasticity between fathers and sons falls at successively higher quantiles from about 0.3 at the $10^{\text {th }}$ percentile to as low 0.16 at the $90^{\text {th }}$. But this is only so in the absence of same firm employment. The results for the interaction term show that the intergenerational transmission of employers is a force working in the opposite direction. There is a greater stickiness in father-son earning outcomes for those who inherit their father's employer, with the increase in the slope being on the margins of statistical significance at the $10^{\text {th }}$ percentile (the marginal significance level of a t-test is 0.065 ), but then rising in magnitude so as to double the elasticity at the $75^{\text {th }}$ percentile and to more than double it at the $90^{\text {th }}$. At the $90^{\text {th }}$ percentile the intergenerational earnings elasticity is 0.158 , but significantly higher at 0.35 when the son is employed by the same main firm as the father. In this sense the results confirm the visual impression from Figure 4. The suggestion is that highachieving sons of low earning fathers must have a greater endowment of characteristics valued in the marketplace than their counterparts with high earning fathers: this endowment compensating them for not having access to the same parental resources associated with the intergenerational 
transmission of employers, and implying that their labour market outcomes would have been even better otherwise.

In Denmark, the overall pattern across the quantiles is the opposite, rising from lowest to highest. Paternal earnings are unrelated to the outcomes of the lowest achieving sons, but much more so for the highest achieving offspring: that is, higher earning fathers are not any more able to influence the outcomes of their sons with the least potential than low earning fathers, but they are more able to do so for sons with the greatest potential. This said, it should be noted that the magnitude of the elasticity at the higher quantiles is in the range of the Canadian findings.

Further, the interaction term for same main employer is positive and statistically significant throughout the son's earnings distribution. Though the magnitude falls above the $10^{\text {th }}$ percentile, at the $90^{\text {th }}$ percentile the overall intergenerational elasticity for those inheriting their father's main employer is about the same in the two countries: just under 0.35 in Canada, and just over 0.32 in Denmark.

\section{Conclusion}

Our result should be understood as descriptive, documenting the nature of the gradient in parentchild outcomes at the later stages of the child's life course and relating this to the structure of labour markets and how young adults make the transition from schooling to work. We find three very similar outcomes in Canada and Denmark, two countries that are characterized by relatively high levels of intergenerational earnings mobility.

First, the intergenerational transmission of employers is a common feature of the employment outcomes of the young cohorts of men we study, with 30 to $40 \%$ of young adults having at some point been employed with a firm that also employed their father. In large measure this is associated with the first jobs these individuals obtain during their teen years, but for four to about six percent it also refers to their main job in adulthood. We do not control for any family 
specific characteristics or investments made during earlier years, and therefore the root causes of these patterns are not clear.

This said, these rather high levels in the incidence of sons ever having worked with the same employer as their fathers may not be out of line with some of the basic facts of how young people find jobs. Families and friends are often cited as the most important source of information for new jobs. Granovetter (1995) was among the first to document this in a small scale survey for a particular labor market, and Holzer (1988) offers the theoretical underpinning by modeling the choice of search methods and suggesting that family and friends are a relatively productive and low cost way of obtaining job offers. More recently Datcher Loury (2006) shows that close to the majority of jobs in the United States are found through family, friends or acquaintances, while Grenon (1999) reports that for Canada about one-quarter of successful job searches involves family or friends. These patterns may differ in a more structured European labor market, but the findings in Kramarz and Skans (2007), whose methods are most closely related to our approach, suggest that they may be broadly applicable. These authors find that there is a high tendency for young adults in Sweden to find their first job in the very same plant that employs their parent.

The incidence of sons ever having worked with the same firm as their fathers in large measure reflects the job search process during the teen years. In both countries this incidence does increase sharply up to about the age of 20 , and at least implies that the intergenerational inheritance of employers during these years may refer to temporary employment during the school to work transition. Even if this is the case it can be understood as a type of parental investment that may have longer term consequences as the sons inheriting a job may be more likely to gain work experience, job tenure and associated general and firm specific human capital. They may also avoid unemployment, and thereby can be imagined to gain a head start in establishing themselves in the longer market over the long term.

Our second major finding is that the intergenerational transmission of employers is positively associated with paternal earnings, rising distinctly and sharply at the very top of the 
earnings distribution. This is robust to a host of controls for the structure of the labor market and characteristics of the firms with which fathers are employed. This finding is new and builds upon Corak and Piraino $(2011,2010)$ by showing that the pattern is robust across two different labor markets.

It may be that the network and other information fathers offer their sons lowers search costs in particular sectors, and that job offers are more likely to be obtained in some firms if the father is or has been employed with those firms. Caliendo et al. (2009) adapt Holzer's model in this way to account for the influence of network effects. Though particular firms may have explicit policies concerning the preferential hiring of the children of employees, this falls short of nepotism in which parents are exerting direct control over the hiring process. Though we do find a strong positive relationship between parental self-employment and the intergenerational transmission of employers, the incidence of the former is not so great as to suggest that direct control over the hiring process is the main reason why 30 to $40 \%$ of sons at some point worked for the same firm as their fathers. Parental networks and information are a more likely story, and should be seen as another type of investment that parents make in the human capital of their children. But the consequences of this influence cannot be understood in isolation of the structure of labor markets.

This said, there is a sense that nepotism may be part of the explanation for some segments of the population, particularly at the very top where we document distinct discontinuities in the relationship between paternal earnings and the chances of being employed with the father's employer. This finds some corroboration in the literature on firm succession. In particular, Bennedsen et al. (2007) examine the succession decisions of limited liability firms, both public and private, in Denmark between 1994 and 2002. They focus specifically on the impact on firm performance of family successions, but they also document that over this period that one-third of successions were family based, in which the new CEO was related through blood or marriage to the departing CEO. Our data may be picking up some of this dynamic, or the more 
general idea that at the highest earning levels parents are more likely to have control over the hiring process and use this in a way that is of benefit for their children. Blanchflower and Oswald (2009), Dunn, and Holtz-Eakin (2000), and Farlie and Robb (2007) describe the very high tendency of self-employed sons to have self-employed fathers and family members, and that this involves, at least with the American data used by Farlie and Robb (2007), the intergenerational transmission of firms in almost $50 \%$ of cases.

Our third finding is that the intergenerational transmission of employers has implications for the intergenerational transmission of earnings. The degree and pattern of intergenerational earnings mobility is very similar in Canada and Denmark, with very similar tendencies for those born to low and high-income fathers to remain in low and high income as adults. But mobility out of the bottom has little to do with inheriting an employer for the father, while the preservation of high income status is distinctly related to this tendency.

While the interpretation of our findings is open to discussion, we follow the suggestions in some of the existing literature to relate the findings to empirical measures of equality of opportunity to suggest that the inheritance of employers cuts against this commonly held value. These findings also raise the importance of recognizing that child outcomes are related to the structure of labor markets, and therefore that the resources parents bring-though information, networks, or direct control of the hiring process - will influence the final transition children make in becoming self-sufficient and successful adults. 


\section{References}

Bennedsen, Morton, Kasper Meisner Nielsen, Francisco Pérez-González, and Daniel Wolfenzon (2007). "Inside the Family Firm: The Role of Families in Succession Decisions and Performance.” Quarterly Journal of Economics. Vol. 122, pp. 647-91.

Blanchflower, David G. and Andrew J. Oswald (2009). “What Makes a Young Entrepreneur?’In Andy Furlong (editor). International Handbook on Youth and Young Adulthood. London: Routledge.

Caliendo, Marco, Arne Uhlendorff, and Ricarda Schmidl (2009). "The Effects of Social Networks on Job Search Behavior and Labour Market Success." Unpublished working paper.

Corak, Miles (2006). "Do poor children become poor adults? Lessons from a cross country comparison of generational earnings mobility.” In John Creedy and Guyonne Kalb (editors). Research on Economic Inequality, Vol. 13. Amsterdam: Elsevier.

Corak, Miles and Patrizio Piraino (2011). "The Intergenerational Transmission of Employers.” Journal of Labour Economics. Vol. 21, pp. 37-68.

Corak, Miles and Patrizio Piraino (2010). "Intergenerational Earnings Mobility and the Inheritance of Employers.” IZA Discussion paper No. 4876.

Datcher Loury, Linda (2006). "Some contacts are more equal than others: Informal networks, job tenure, and wages.” Journal of Labour Economics. Vol. 24, pp. 299-318.

Dunn, Thomas and Douglas Holtz-Eakin (2000). "Financial Capital, Human Capital and the Transition to Self-Employment: Evidence from Intergenerational Links.” Journal of Labour Economics. Vol. 18, pp. 282-305.

Fairlie, Robert W. and Alicia M. Robb (2007). "Families, Human Capital, and Small Business: Evidence from the Characteristics of Business Owners Survey.” Industrial and Labour Relations Review. Vol. 60 No. 2, pp. 225-245 
Grawe, Nathan D. (2004). "Intergenerational mobility for whom? The experience of high- and low-earnings sons in international perspective.” In Miles Corak (editor). Generational Income Mobility in North America and Europe. Cambridge: Cambridge University Press. Grenon, Lee (1999). “Obtaining a job.” Perspectives on Labour and Income. Ottawa: Statistics Canada, catalogue number 75-001.

Harmon, C., I. Walker and N. Westergaard-Nielsen, Introduction in Harmon, C.,I. Walker and N. Westergaard-Nielsen (eds.): Education and Earnings in Europe, 2001, Elgar.

Holzer, Harry J. (1988). “Search Method Use by Unemployed Youth.” Journal of Labour Economics. Vol. 6, pp. 1-20.

Ionnides, Yannis M. and Linda Datcher Loury (2004). "Job Information Networks, Neighborhood Effects, and Inequality.” Journal of Economic Literature. Vol. 42, pp. 1056-93.

Kramarz, Francis and Oskar Nordström Skans (2007). "With a little help from my ... Parents? Family Networks and Youth Labour Market Entry.” CREST Working Paper.

Roemer, John E. (2004). “Equal Opportunity and Intergenerational Mobility: Going Beyond Intergenerational Income Transition Matrices.” In Miles Corak (editor). Generational Income Mobility in North America and Europe. Cambridge: Cambridge University Press.

Rosenzweig, M. R. and K. I. Wolpin (1985). "Specific experience, household structure and intergenerational transfers: farm family land and labour arrangements in developing countries." Quarterly Journal of Economics. Vol. 100, pp. 961-87.

Shea, John (2000). “Does Parents' Money Matter?” Journal of Public Economics. Vol. 177, pp. $155-84$

Solon, Gary (1992). "Intergenerational Income Mobility in the United States.” American Economic Review. Vol. 82, 393-408.

Solon, Gary (1989). "Biases in the Estimation of Intergenerational Earnings Correlations." Review of Economics and Statistics. Vol. 71, pp. 172-74. 


\section{Data Appendix}

The descriptions of the two sets of administrative data that follow pertain to the complete underlying data. It is on the basis of these data that analytical files appropriate for a comparative analysis will be derived involving similar cohorts of individuals and the analysis of similar points in their life cycles.

Danish Data - the IDA

\section{Sampling frame and representativeness}

The data is known as the IDA and is based on Danish administrative registers. It follows the entire Danish population from the year 1980, and is available on an annual basis up to 2007.

The register starts in 1980 with detailed information. The link between parents and children is established in 1970 at the last census held in 1970. The link is established for all children living with their parents at that time. As most children in Denmark live with their parents to the age of 14 at least, this means that the register covers the link for all those born after 1956 and will cover a substantial part of those born before because at that time leaving the parental home happened at a later stage of life. In 1980, the 1956 cohort was 24 years old. We can then follow this generation until 2007 where they will be 51 years old or younger. The parents can of course be followed from the time where the children had become 24 .

The basis of this research proposal will more likely be parents and children at the time the children turn 14. These children can be followed from 1980, meaning that we can include the cohorts born after 1966. They are expected to have 14 year old children themselves when they turn 40-41 in 2007. Similarly, a link can be established to siblings. Furthermore, a number of these $2^{\text {nd }}$ generation children born in 1980 or before would be 27 or more in the last year of the register in 2007. Thus, we are close to having 3 generations.

There will be attrition in the panel due only to natural causes (emigration and death).

\section{Detailed variable description}

Parental Resources (P) include income and wage income of both parents, available on an annual basis. Furthermore, we know the education of the parents and siblings and when the education was received as well as home ownership. Job situation, regional address and similar information are also available.

All variables are measured on an annual basis. The information is highly reliable since it originates in registers. But most importantly for present purposes we also know the identity of the workplace or firm, where the father or mother was working in any year after 1980.

The information on $\mathrm{C} 2, \mathrm{C} 3$ and $\mathrm{P}$ can be measured at the time the child is born to 16 years of age. The cost of choosing a young age is fewer observations for the outcome variable.

With respect to outcomes, we know the income, education and house ownership of the offspring in any particular year or age. We also know where the children were employed for the first job or apprentice training, as well as all subsequent jobs. Firms and workplaces regularly change identity over time, but due to a specific data development work we are in a position to construct a 
longitudinally consistent firm identifier. Thus, we can identify if the offspring has been employed at the same work place as either the father or mother.

\section{Control variables}

In addition to full information on the nature of parental income and basic demographic information, the data offer the capacity to control for region, age and siblings, year, marital status, local conditions depending on municipality (schools). Furthermore, we have information on the foreign born. The latter is measured for all immigrants, simply because they are given their social security number later in life.

\section{Canadian Data - the IID}

\section{Sampling frame and representativeness}

The data is known as the IID (the Intergenerational Income Data) and is based on administrative data associated with Canadian income tax information returns linked into families over time. It is housed at Statistics Canada.

Canadians file their income tax returns (so-called T1 Forms) on an individual basis, and Statistics Canada has grouped these into families using a variety of matching strategies. This involves the use of administration data on a universal program of child allowances in place during the 1970s and 1980s, address information, and names. The resulting T1 Family File (T1FF) is the basic building block for the creation of the IID, an intergenerational linked set of T1 Forms for a series of cohorts of young men and women, and their mothers and fathers.

This represents not quite four million individuals and their parents, involving a number of age cohorts. We focus on the cohort born between 1963 and 1966, and in fact for the most part the oldest subset born in 1963. These individuals are linked to their fathers - not necessarily their biological fathers - if they filed an income tax return between 1982 and 1986 while still living at home. This is required to ensure that a parent-child match is made, and also that the child has an observed Social Insurance Number (SIN), a unique individual identifier that can then be used to link all subsequent T1 Forms which contain information on earnings.

These T1 Forms are available for all years between 1978 and 1996. The algorithm used to create the data leads to an under-representation of children from lower income backgrounds, and from the major metropolitan areas: Montreal, Toronto, and Vancouver. This reflects the fact that children who leave home early or who otherwise are not engaged in the labour market while at home are less likely to be linked to a parent. It also reflects the fact that new immigrants and their children will be under-represented in the data, the majority having a tendency to settle in the three major cities of the country. The nature of this under-reporting has been explored in a number of research documents. In a series of published research papers it is not found to play a role in biasing analytical results.

The IID is supplemented with a series of weights derived from the Census of the population in order to account for this underreporting. Our analysis will use these weights. 


\section{Detailed variable description}

Parental Resources includes income and earnings of both parents, available on an annual basis. Furthermore, there is detailed information on the source of income, including self-employment income and income from other sources, including government transfers. There is no information on the education of parents, and children, and sibling information is available only for those siblings present in the household at the time the family linkage was made. Other basic demographic information such as gender, address of residence, and marital status is also available.

All variables are measured on an annual basis. The information is highly reliable since it originates in registers. The identity of the enterprise, where the father, mother, and children work is determined through a linkage to a longitudinally consistent dataset of all firms in Canada from 1978 to 1996, also produced by Statistics Canada. This dataset corrects for any changes in firm status through time, including mergers and bankruptcies. The firm identifiers are available for up to four firms per year in each year. These firms represent the top four firms accounting for annual earnings in that year. Up to $97 \%$ of all earnings are accounted for by these employers.

The information on $\mathrm{C}$ and $\mathrm{P}$ can be measured at the time the child is from 15 onward.

Child outcomes include income, earnings, government transfers and region of residence in any particular year or age, as well as the employer (this also includes the three digit industry of the employer) for all employers (again up to four per year) the child has had since the age of 15 to about the age of 30. For the oldest cohort this involves using information from 1978 to 1996. As such we can identify if the child has been employed at the same work place as either the father or mother and at what point in the life cycle this has occurred.

The firm data is based upon an accurate representation of the private sector but our analysis of the intergenerational transfer of employers is hampered by the fact that it does not distinguish separate employers in the public sector (the federal and provincial governments, but not the municipal governments). For anything finer than a two-digit industry analysis this will overstate the degree to which employers or industries are passed across the generations.

\section{Control variables}

In addition to full information on the nature of parental income and basic demographic information, the data offer the capacity to control for detailed region of residence, age and siblings (though as mentioned this is not complete), year, marital status, local labour market conditions and community characteristics, firm size and industry. Furthermore, there is no information on the foreign born. 
Appendix Table 1

Quartile earnings transition matrix with proportions of intergenerational transmission of employers within each cell: Canada and (Denmark)

A. Father-son earnings quartile transition matrix

Sons

\begin{tabular}{r|cccc}
\multicolumn{1}{l|}{ Fathers } & Bottom & $2^{\text {nd }}$ & $3^{\text {rd }}$ & Top \\
\hline Bottom & $0.351(0.304)$ & $0.282(0.302)$ & $0.207(0.233)$ & $0.161(0.161)$ \\
$2^{\text {nd }}$ & $0.267(0.254)$ & $0.277(0.288)$ & $0.254(0.258)$ & $0.202(0.200)$ \\
$3^{\text {rd }}$ & $0.215(0.231)$ & $0.238(0.240)$ & $0.277(0.269)$ & $0.271(0.259)$ \\
Top & $0.168(0.210)$ & $0.203(0.170)$ & $0.262(0.240)$ & $0.367(0.380)$
\end{tabular}

B. Proportion of sons with the same main employer as father within each cell of the earnings quartile

Sons

\begin{tabular}{r|cccc}
\multicolumn{1}{l|}{ Fathers } & Bottom & $2^{\text {nd }}$ & $3^{\text {rd }}$ & Top \\
\hline Bottom & $0.041(0.033)$ & $0.048(0.042)$ & $0.038(0.032)$ & $0.042(0.023)$ \\
$2^{\text {nd }}$ & $0.027(0.024)$ & $0.059(0.050)$ & $0.067(0.049)$ & $0.061(0.028)$ \\
$3^{\text {rd }}$ & $0.022(0.020)$ & $0.046(0.042)$ & $0.083(0.054)$ & $0.101(0.036)$ \\
Top & $0.029(0.024)$ & $0.044(0.043)$ & $0.079(0.059)$ & $0.116(0.067)$
\end{tabular}


Table 1

Selected results from linear probability models of the correlates of sons having the same employer as their fathers: Canada and Denmark

\begin{tabular}{lcc} 
& Canada & Denmark \\
\cline { 2 - 3 } & & \\
1. Sons ever having same employer as father & & -0.718 \\
$\quad$ In of father's permanent earnings & -0.486 & 0.070 \\
$\quad$ In of father's permanent earnings squared & 0.0431 & 0.338 \\
$\quad$ Indicator father having self-employment income & 0.0476 & \\
2. Sons having same main employer as father & & -0.359 \\
$\quad$ In of father's permanent earnings & -0.242 & 0.0220 \\
In of father's permanent earnings squared & 0.0175 & 0.0370 \\
$\quad$ Indicator father having self-employment income & 0.0054 & \\
\hline
\end{tabular}

Source: Calculations by authors using least squares regression using Danish administrative data, Corak and Piraino (2011, tables 4 and 5) for Canadian results based upon Canadian administrative data.

Panel 1 reports results from a linear probability model with the dependent variable being a 0-1 indicator of whether the son at any point between the ages of 15 and 30 worked for an employer for which his father had previously worked. The overall incidence of this occurring is presented as the last data point in Figure 1, approximately 0.40 in Canada and 0.28 in Denmark.

Panel 2 reports results from a similar model, but with the dependent variable being a 0-1 indicator of whether the son's main employer in adulthood, the employer accounting for the majority of earnings, was the same main employer of the father when the son was a teenager. The overall incidence of this occurring is 0.056 in Canada and 0.041 in Denmark.

All results are statistically significant at the $95 \%$ level of confidence.

Other controls in both models include: indicators for presence of farming, fishing, and professional income; indicators for firm death and firm size; industry employment growth rate; average years of schooling in 2-digit industry; urban indicator, province/region indicators; 2-digit industry indicators; interactions between earnings, and schooling, and self-employment income. 
Table 2

Quantile regression estimates of the intergenerational earnings elasticity and the impact of same main firm employment

\begin{tabular}{|c|c|c|c|c|c|c|}
\hline & \multicolumn{2}{|c|}{ No Interactions } & \multicolumn{4}{|c|}{ Fully Interacted model } \\
\hline & $\ln Y$ & Constant & $\ln Y$ & $\begin{array}{c}\ln Y \times \\
\text { SameFirm }\end{array}$ & SameFirm & Constant \\
\hline \multicolumn{7}{|l|}{ 1. Canada } \\
\hline $10^{\text {th }}$ percentile & 0.328 & 5.86 & 0.309 & 0.128 & -0.938 & 5.99 \\
\hline $25^{\text {th }}$ percentile & 0.308 & 6.71 & 0.291 & 0.158 & -1.43 & 6.83 \\
\hline $50^{\text {th }}$ percentile & 0.253 & 7.48 & 0.238 & 0.177 & -1.74 & 7.61 \\
\hline $75^{\text {th }}$ percentile & 0.205 & 8.45 & 0.190 & 0.196 & -2.01 & 8.59 \\
\hline $90^{\text {th }}$ percentile & 0.170 & 9.05 & 0.158 & 0.190 & -1.98 & 9.15 \\
\hline \multicolumn{7}{|l|}{ 2. Denmark } \\
\hline $10^{\text {th }}$ percentile & 0.051 & 8.93 & 0.036 & 0.180 & -1.84 & 9.29 \\
\hline $25^{\text {th }}$ percentile & 0.132 & 9.65 & 0.123 & 0.135 & -1.58 & 9.77 \\
\hline $50^{\text {th }}$ percentile & 0.178 & 9.47 & 0.169 & 0.133 & -1.62 & 9.56 \\
\hline $75^{\text {th }}$ percentile & 0.195 & 9.49 & 0.188 & 0.138 & -1.72 & 9.56 \\
\hline $90^{\text {th }}$ percentile & 0.197 & 9.70 & 0.191 & 0.132 & -1.67 & 9.77 \\
\hline
\end{tabular}

For the fully ineracted model the reported coefficients are quantile regression estimates of the following model:

$\ln Y_{i, t}=\alpha+\beta \ln Y_{i, t-1}+\beta_{1} \ln Y_{i, t-1} \times$ SameFirm $_{i}+\gamma_{1}$ SameFirm $_{i}$

where $t$ indexes the son's permanent earnings and $\mathrm{t}-1$ the fathers. SameFirm is a binary indicator of whether the son was employed by the same employer as the father. The model also includes controls for the father's age and age squared.

The no interactions model only has $\ln Y_{i, t-1}$ as a regressor.

All coefficients have margin significance levels of 0.000 , except those lightly shaded, which have a marginal significance level greater than 0.05 .

For Canada the sample size is 71,215 ; for Denmark it is 191,471 . 


\section{Figure 1}

Proportion of sons currently employed or employed at some point with an employer their fathers had worked for in the past: Canada and Denmark

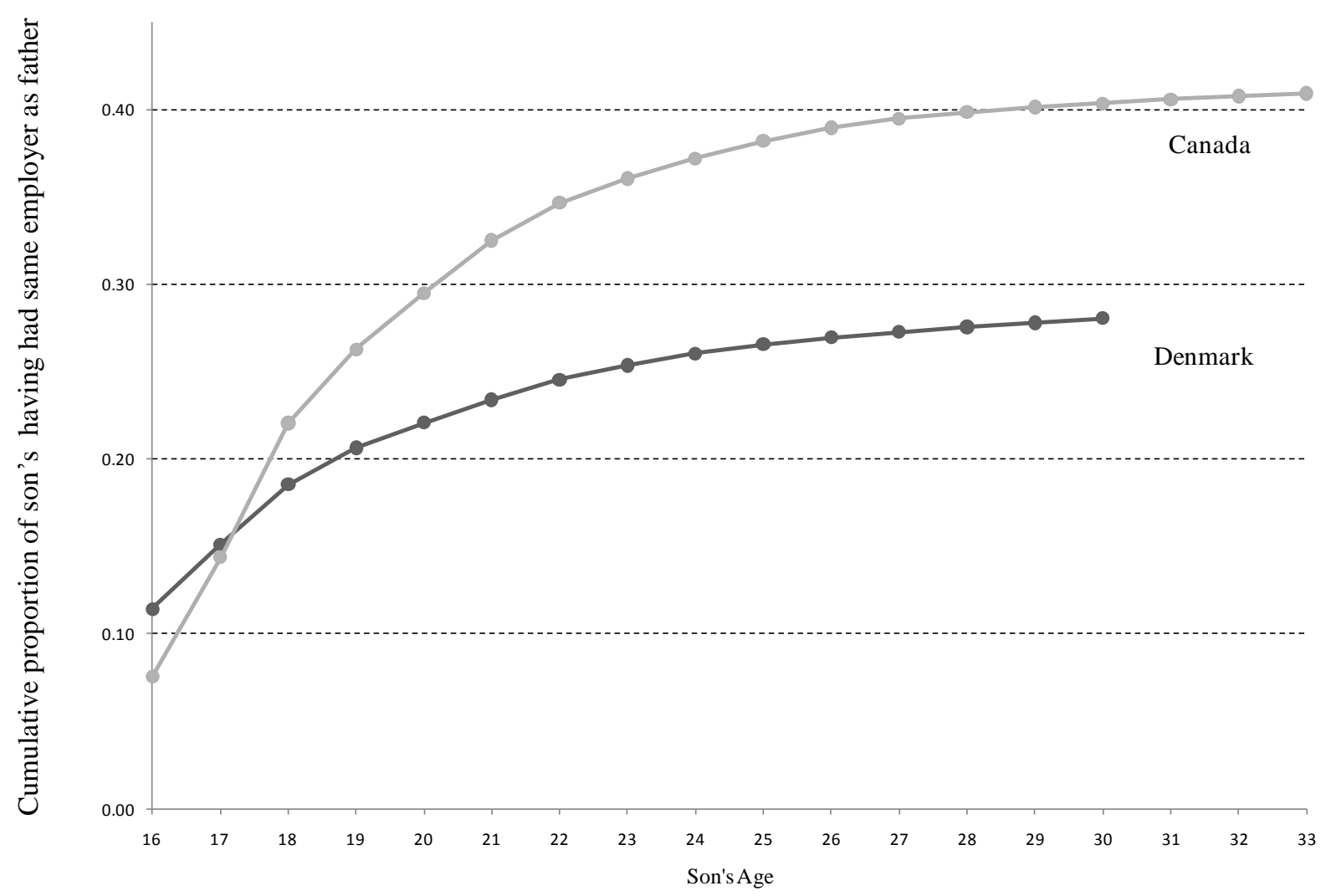

Source: Calculations by authors using administrative data, Corak and Piraino (2011, figure 1). 
Figure 2

Proportion of sons currently employed or employed at some point with an employer their fathers had worked for in the past: Canada and Denmark, by fathers' earnings percentile

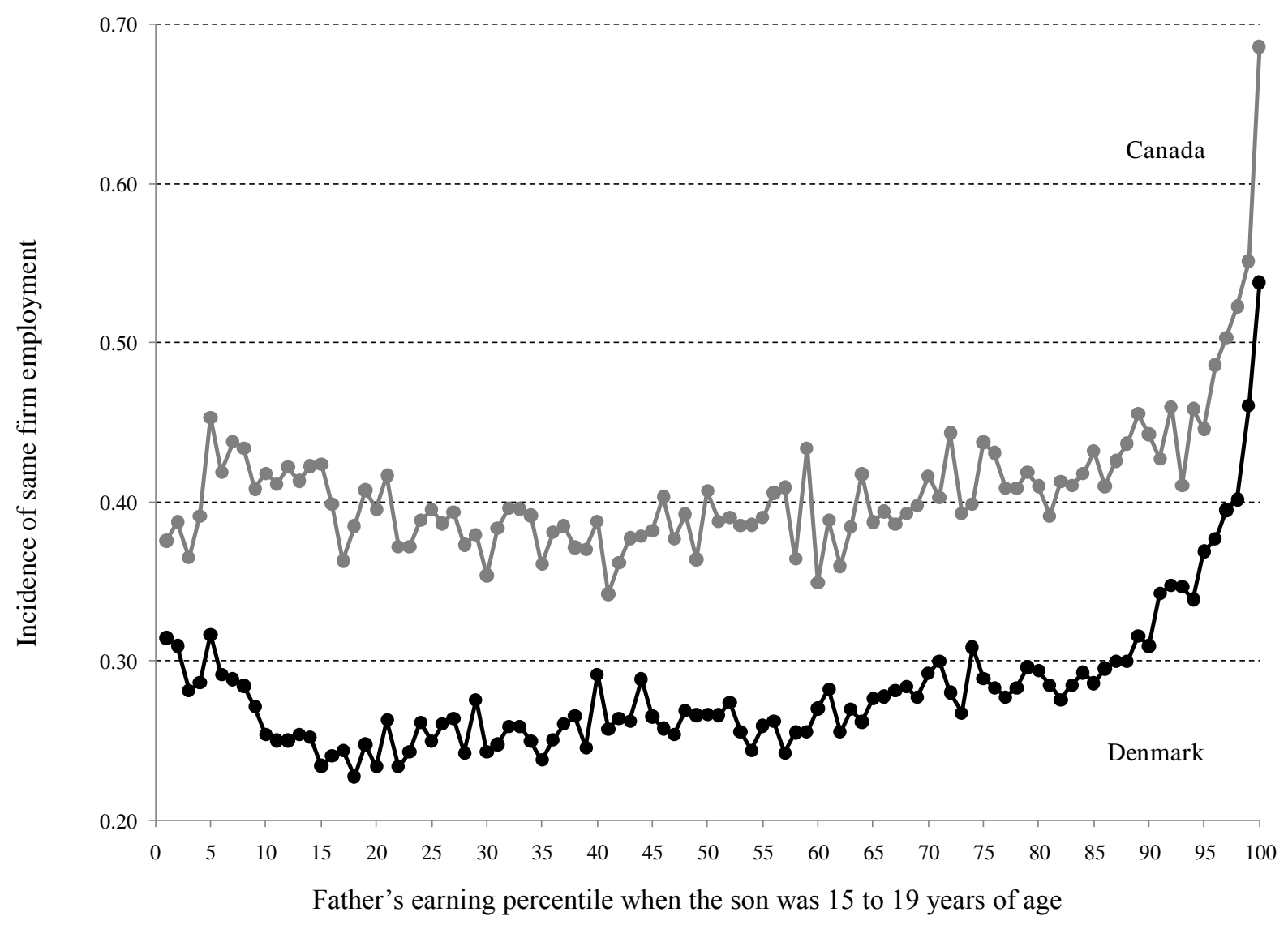

Source: Calculations by authors using administrative data, Canadian information from Corak and Piraino (2011, figure 2). 
Figure 3

Proportion of sons employed as young adults with the same main employer as their fathers:

Canada and Denmark, by fathers' earnings percentile

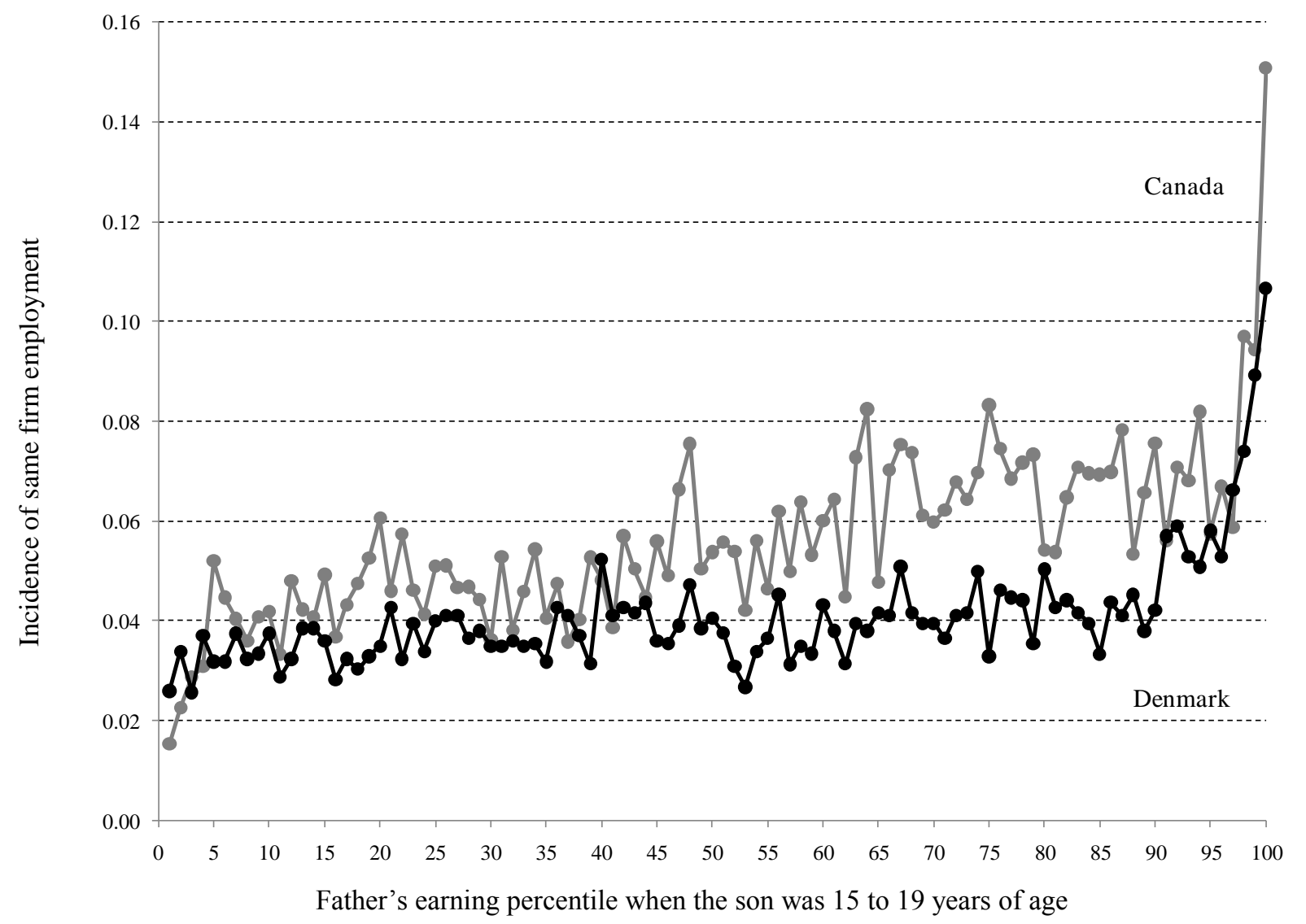

Source: Calculations by authors using administrative data, Canadian information from Corak and Piraino (2010). 
Figure 4

The association between earnings mobility and the transmission of employers for sons raised in the bottom and top earnings quartiles: Canada and Denmark

\section{A. Earnings mobility for sons of bottom and top earning fathers}
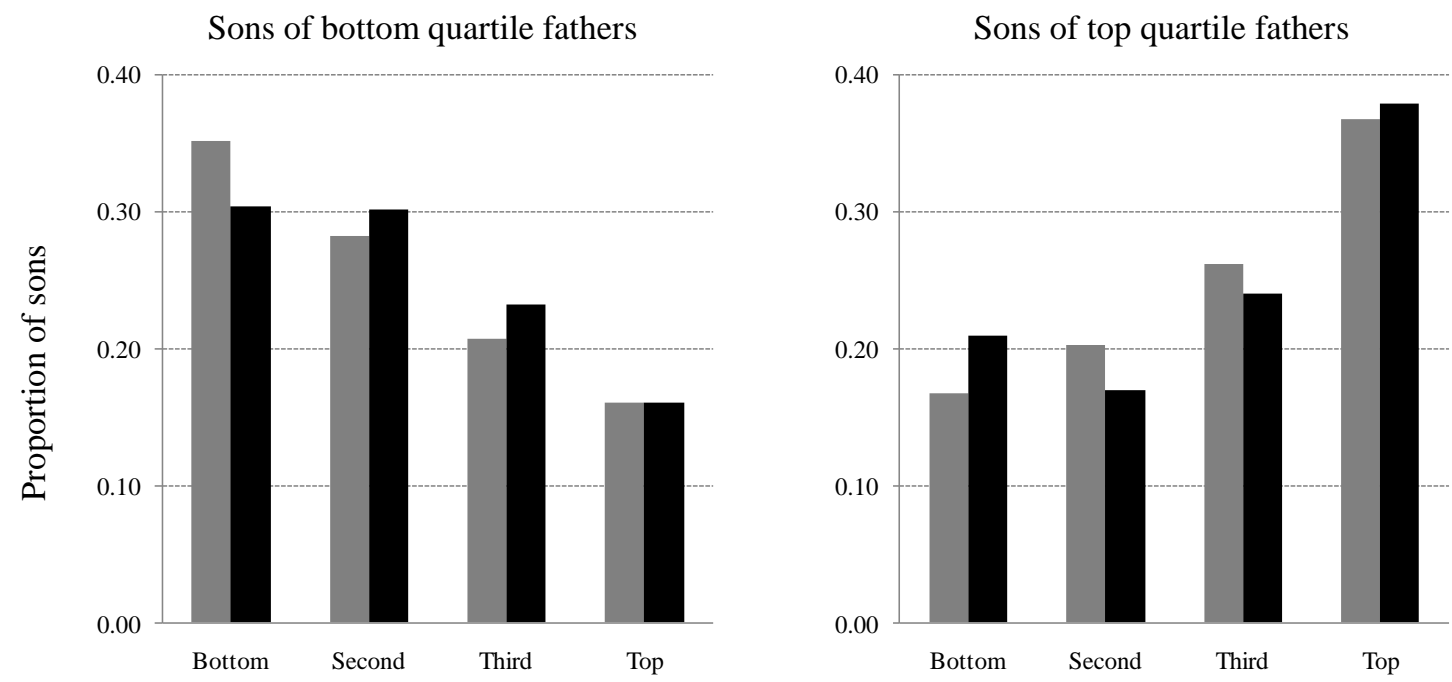

B. Incidence of same main employer by sons' earnings quartile
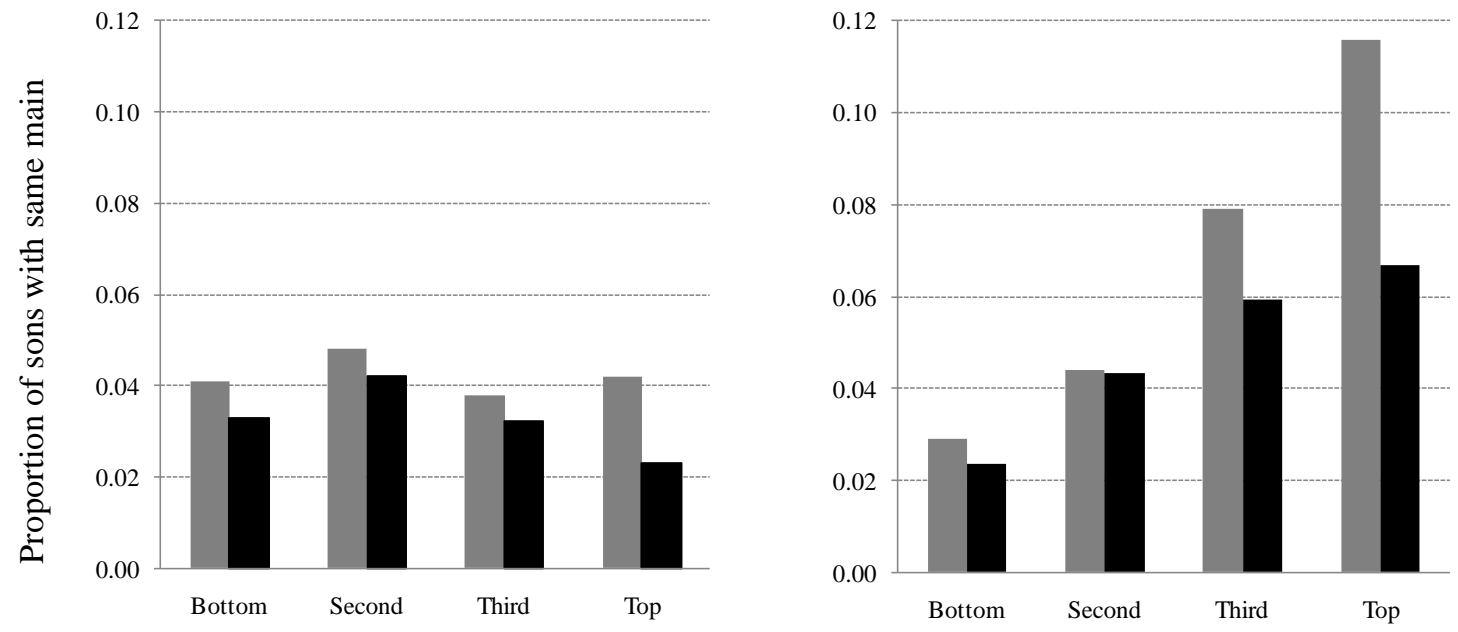

Sons' earnings quartile in adulthood

Source: Calculations by authors using administrative data.

Gray bars indicate Canada, dark bars indicate Denmark. 